\title{
Proporcionalita opatření přijímaných ve výjimečných stavech*
}

\section{Proportionality of Measures Adopted in the Emergencies}

\author{
Pavel Ondřejek ${ }^{* *}$
}

\begin{abstract}
Abstrakt
O principu proporcionality se právem hovoř́ jako o kličovém argumentu prì prękumu ústavnosti zásabu do základnich práv. Nedávné události v souvislosti s epidemií nemoci COVID-19 ukázaly, že zásaby do základnich práv mohou být dloubodobé, citelné a značnè omezujicí v porovnánísprèdchozípraxí. Základní tęi tohoto př̌spèvku je zdivvodnèni potreby argumentace proporcionalitou pri pręleumu ústavnosti opatreni prijimaných ve výjimečných stavech. Mimo jiné je argumentováno, že požadavek, proporcionality jakožto univeráálního kritéria prękumu üstavnosti posiluje koherenci práva, a tím i predvídatelnost rozhodnutí

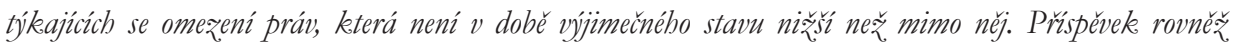
naznačuje specifika aplikace principu proporcionality ve vətabu ke opatrením prïjatým ve výjimečných stavech, konkrétně zvýšnenou miru nejistoty, potrebu zvýšené míry zdržentivosti, jakož $i$ otázky argumentačního bremene prì argumentaci proporcionalitou.
\end{abstract}

\section{Klíčová slova}

Lidská práva; princip proporcionality; výjimečné stavy; prosystémový výklad práva; koherence podminek limitace základnich práv.

\section{Abstract}

The principle of proportionality is rightly referred to as a key argument in constitutional review in case of an interference with fundamental rights. Recent events related to the COV ID-19 pandemic have shown that those interferences may be long-lasting, substantial, and severely limiting in comparison with the previous practice. The basic thesis of this contribution is to illustrate that proportionality is the proper test of constitutional review of measures adopted in emergencies. Among other things, it is argued that the requirement of proportionality as a universal criterion for constitutional review strengthens the coherence of the law, and thus the foreseeability of requirements to limit rights, which is equally important in times of emergency as it is under normal circumstances. The article suggests the specificities of the application of principle of proportionality in the emergencies, especially the bigher degree of uncertainty, the need for a judicial restraint and the issue of the burden of argumentation.

\footnotetext{
* Př́́spěvek vznikl v rámci projektu GAČR č. 19-10723S s názvem „Co současné právo sjednocuje a co jej fragmentarizuje z pohledu právní teorie a soudní praxe?" První verze př́spěvku byla prezentována na konferenci Weyrovy dny právní teorie 2020 konané příznačně pro jarní měsíce roku 2020 distančně. Mé poděkování za cenné připomínky a komentáře k článku patří oběma anonymním recenzentům, Janu Wintrovi, Martinu Haplovi, hlavnímu organizátorovi konference Weyrovy dny právní teorie, stejně jako dalším jejím účastníkům.

** Doc. JUDr. Pavel Ondřejek, Ph.D., Katedra teorie práva a právních učení, Právnická fakulta, Univerzita Karlova, Praha / Department of Legal Theory and Legal Doctrines, Faculty of Law, Charles University, Prague, Czech Republic / E-mail: ondrejek@prf.cuni.cz / ORCID: 0000-0001-6764-8993
} 


\section{Keywords}

Keywords: Human Rights; Proportionality Principle; Emergency Regulation; Pro-systemic Legal Interpretation; Coherence of Conditions for Limitations of Fundamental Rights.

\section{Úvod}

Tento příspěvek se zabývá jedním z mnoha aspektů opatření přijatých ve výjimečných stavech, a to přiměřeností (proporcionalitou) zásahů do základních práv, která tato opatření způsobují. Zkoumání proporcionality představuje klíčový argument při přezkumu jejich ústavnosti a cílem tohoto článku bude argumentovat, že při meritorním přezkumu ústavnosti každého opatření musí být kritérium proporcionality vždy zkoumáno. ${ }^{1}$ Tento přezkum nemůže být nahrazen jiným testem, i když vezmeme $v$ úvahu fakt, že opatření přijímaná $\mathrm{v}$ době výjimečného stavu mohou být $\mathrm{v}$ řadě ohledů specifická. Důvod, proč se věnuji právě proporcionalitě opatření přijatých ve výjimečných stavech, je zřejmý: v České republice byly od března 2020 prrijaty desítky více či méně obecně formulovaných opatření (vlády, Ministerstva zdravotnictví, ale i zákonů přijatých Parlamentem), které jako hlavní účel deklarovaly zvládnutí epidemie nemoci COVID-19, př́padně souvisejících, zejména ekonomických, škod či hrozeb. ${ }^{2}$

Zároveň se od dubna v České republice začala objevovat první soudní řízení, v nichž byla mimo jiné napadána disproporcionalita těchto opatření. Ze strany navrhovatelů zazněly např́klad argumenty, podle nichž jsou příslušná protiepidemická opatření disproporcionální, protože:

- jsou př́liš plošná z hlediska osobní působnosti, a tedy dostatečně nereflektující fakt, že ne všechny osoby jsou ohroženou skupinou nemocí COVID-19, ${ }^{3}$

1 K základním doktrinárním př́stupům $\mathrm{k}$ principu proporcionality $\mathrm{v}$ soudobé ústavní a právní teorii viz ČERVÍNEK, Zdeněk. Proporcionalita. In: SOBEK, Tomáš, Martin HAPLA a kol. Filosofie práva. Brno: Nugis Finem Publishing, 2020, s. 365-371.

2 Opatření vlády jsou dostupná z: https://www.vlada.cz/cz/epidemie-koronaviru/dulezite-informace/ prehled-vladnich-usneseni-od-vyhlaseni-nouzoveho-stavu-180608; Mimořádná opatření Ministerstva zdravotnictví jsou dostupná z: http://www.mzcr.cz/obsah/aktualni-mimoradna-opatreni-a-rozhodnuti-ke-covid-19_4135_1.html; Jak však upozorňuje Jan Wintr, Ministerstvo zdravotnictví na konci května 2020 začalo z přehledu na svých internetových stránkách odstraňovat starší mimořádná opatření, která byla bud' zrušena, nebo nahrazena novými - viz WINTR, Jan. K ústavnosti a zákonnosti opatření proti epidemii v jarních měsících roku 2020. Správní právo, 2020, č. 5-6, s. 296.

3 Rozsudek Městského soudu v Praze ze dne 7. 5. 2020, sp.zn. 10 A 35/2020-261, bod 4: „Mimorádné opatrené bylo dle názoru žalobkynè neprìmèrené, protože u dètí se nemoc covid-19 projevuje jen mírnými prǐznaky, a tedy

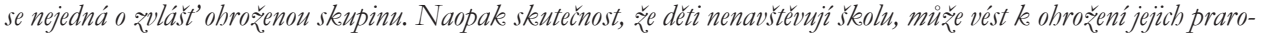
diču, kterí musi o dèti ve zvýšené míre pečovat. "Ponechme nyní stranou přesvědčivost argumentu, že prarodiče dětí o ně musejí ve zvýšené míře pečovat. 
- jsou př́liš široká z hlediska věcné působnosti (tedy předmětu regulace), zejména ve srovnání s jinými zdravotními hrozbami, ${ }^{4}$

- nereflektují jiné možnosti regulace, které omezují základní práva méně, avšak jsou s to dosáhnout sledovaného cíle, ${ }^{5}$

- nedostatečně zdůvodňují, proč právě konkrétní aktivita je omezena či zakázána, přestože jiné podobné aktivity zůstávají povoleny, ${ }^{6}$

- jsou nedostatečně odůvodněna odbornými informacemi. ${ }^{7}$

Výše uvedené argumenty navrhovatelů směřovaly proti určitému opatření, přičemž nikdy se nejednalo o individuální právní akt, nýbrž podle okolností o opatření obecné povahy, anebo právní akt vlády, který většina soudcư Ústavního soudu hodnotila zprvu jako právní předpis sui generis, posléze jako právní předpis, protože materiálně splňoval kritéria obecně závazného normativního právního aktu. ${ }^{8}$ Právě toto hodnocení povahy

4 Usnesení Ústavního soudu ze dne 5. 5. 2020, sp. zn. Pl. ÚS 12/20, bod 6: „... Konečně je pak namítána neprimèrenost prijatébo opatreni se zduivodnèním, že v dobè jeho vydáni bylo na územi Ceské republiky potvrzeno 38 př́padũ onemocnèni S ARS-CoV-2, což je v brubém nepomèru s epidemii sezónni chrípky, kterou podle Pandemickébo plánu Céské republiky (dále jen ,pandemický plán') onemocni z̧hruba pèt set tisic ažj jeden milion obyvatel ročnè. $V$ této nepriměrenosti spatruji stěžovatelky porušeni $\int 2$ odst. 3 správníbo rádu, vątabujicíbo se na výkon veškeré správni cuinnosti. "

5 Usnesení Ústavního soudu ze dne 22. 4. 2020, sp. zn. Pl. ÚS 8/20, bod 10: „Konečně (za páté) stěžovatelkea namitá, že jou napadená opatreni nepriměrená - za efektivnèjsi a méné omezujici alternativu stéžovatelka považuje napřklad zdravotni kontroly obyvatelstva či separaci osob vyšš́ho věkeu. "; usnesení Ústavního soudu ze dne 5. 5. 2020, sp. zn. Pl. ÚS 13/20, bod 12: „Zadrubé, stě̌̌ovatel broji proti omezeni pobybu uvnitř státu a možnosti jej opustit. Porušeni své svobody pohybu (a v̌̌ech osob żdř̌ujicich se na územi Ceské republiky) spatruje v neprimèreném uzavrení branic, lze-li napríklad nař́dit individuální karanténu po návratu ze zabraniči. "

6 Návrh skupiny senátorů ze dne 8. 10. 2020 na zrušení části krizového opatření vlády ČR dle usnesení č. 958 ze dne 30. 9. 2020, bod II.3., publikovaného pod č. 392/2020 Sb., řízení sp. zn. Pl. ÚS 102/20, odst. 19 a 20 návrhu. (dostupné z: https://www.usoud.cz/projednavane-plenarni-veci). V předmětném návrhu šlo o omezení počtu osob na bohoslužbách limitem 100 osob a dále o zákaz zpěvu na náboženských obřadech. Navrhovatelé argumentují jednak tím, že „vláda nedoložila žádné podkladové studie..., které by prokazovaly, že v Ceské republice pri náboženských obradech dochází k výraznému prenosu virové infekce nemoci covid19", dále pak tím, že „vláda nedoložila žádné podkladové studie, které by prokazovaly, že zpèvem i pres dodržení všech bygienických standardu (roušky, rozestupy a sociálni distanc) prí náboženských obradech docházi v České republice ke výraznému prénosu virové infekece nemoci covid-19. "Zdůrazňování zvláštní výjimečnosti bohoslužeb je patrné z řady míst návrhu, např́klad ze srovnání: ,vláda nijak nezdivodnila, proč považuje za nutné z hlediska šireni viru SARSCoV-2 prǐsně regulovat chrámy víry, avšak neregulovat, chrámy konzumu! " (odst. 40 výše citovaného návrhu).

7 Usnesení Ústavního soudu ze dne 5. 5. 2020, sp. zn. Pl. ÚS 10/20, bod 11: „[Stěžovatel s]oublasí s nez̧bytnosti provedeni urǔitých opatřeni a wědomuje si, že je tréba drislednè chránit slabši jedince ve společnosti. Nelz̨e tak ovšem činit absolutně na úkor veškerého dalš̉ho života společnosti. Jakekoli proto považzje nékteré kroky vlády za nezbytné a samožrejmě se jim rád podřdí, v̌̌dy musí jit o kroky odīvodnèné, podložené odbornými informacemi. "

8 Ke změně hodnocení povahy opatření vlády, ke kterému došlo v rozmezí přibližně dvou týdnů mezi přijetím prvních dvou a další skupiny nálezů Ústavního soudu, viz odlišná stanoviska soudce Vladimíra Sládečka k usnesením Ústavního soudu sp. zn. Pl. ÚS 13/20 ze dne 5. 5. 2020 a sp. zn. Pl. ÚS 15/20 ze dne 5. 5. 2020. V podrobnostech viz též WINTR, Jan. K ústavnosti a zákonnosti opatření proti epidemii v jarních měsících roku 2020. Správníprávo, 2020, č. 5-6, s. 286 a násl.; WINTR, Jan. Principy českébo ústavního práva. 5. vyd., Plzeň: Aleš Čeněk, 2020, s. 229-230; Vlastní hodnocení dané problematiky detailněji popsal soudce V. Sládeček v článku SLÁDEČEK, Vladimír. Vláda a nouzový stav. Správníprávo, 2020, č. 5-6, s. 266-281. 
dotčeného aktu bylo většinou určující pro výsledek sporu. Pokud se před Ústavní soud dostala stížnost, soudci většinou hlasů ve všech př́ípadech rozhodli o jejím odmítnutí, nebot' byla podána osobou neoprávněnou (jeden z hlavních argumentů $v$ této souvislosti byl, že v prrípadě přiznání aktivní legitimace by se v českém právním řádu objevila actio popularis). ${ }^{9}$ Argumenty proporcionalitou právní úpravy se tak v případě nálezů Ústavního soudu vưbec meritorně neprojednávaly a totéž bylo možné až do 11. listopadu 2020 (tedy téměř osm měsíců od vyhlášení prvního nouzového stavu v důsledku epidemie nemoci COVID-19) říci i o rozsudcích pražského Městského soudu. ${ }^{10}$

První, a tedy ojedinělé rozhodnutí, v němž český soud meritorně zkoumal princip proporcionality, byl rozsudek Městského soudu v Praze ze dne 11. listopadu 2020, v němž tento soud zamítl žalobu míŕící proti důsledkům mimořádného opatření vlády ze dne 30. března 2020 č. 334 (vyhlášeného pod č. 142/2020 Sb.), kterým vláda mimo jiné zakázala přeshraničním pracovníkům vycestovat z území České republiky do Německa a Rakouska, s výjimkou př́padů, pokud by vycestovali na dobu delší než 21 dní. ${ }^{11}$ Žalobkyně byla samoživitelka pečující o dvě děti, takže její vycestování za hranice na minimálně tři týdny nepřicházelo v úvahu. Městský soud nakonec žalobu zamítl, když aplikoval vưči postupu vlády deferenční (zdrženlivý) př́istup, přičemž důležitým argumentem bylo právě zhodnocení proporcionality daného opatření. ${ }^{12}$

Přestože k meritornímu přezkumu proporcionality právního aktu došlo zatím v ojedinělém př́padě, považuji bližší zkoumání tohoto kritéria přezkumu ústavnosti opatření přijatého ve výjimečném stavu za velmi podstatné. ${ }^{13}$ Jedním z důvodů je stabilita výkladu omezení základních práv, což má vliv na posilování právní jistoty adresátů práva, která

9 Neuspěl ani protiargument, podle něhož normativním aktem dochází k individualizovanému zásahu do základního práva stěžovatele. Viz odst. 25 odůvodnění usnesení Ústavního soudu ze dne 5. 5. 2020 sp. zn. Pl. ÚS 13/20. S tímto závěrem nesouhlasila soudkyně Kateřina Šimáčková, která v disentech k několika rozhodnutím požadovala meritorní projednání prípadu s odkazy na judikaturu Evropského soudu pro lidská práva, který právě meritorní projednání v prrípadech individualizovaného zásahu normativním aktem připouští - viz např. odlišné stanovisko soudkyně K. Šimáčkové k výroku i odůvodnění usnesení sp. zn. Pl. ÚS 13/20.

10 Jan Petrov kritizoval skutečnost, že k substantivnímu přezkumu opatření přijatých v České republice nedošlo kvůli formalistickému př́istupu některých soudců obecné justice a minimalistickému př́stupu Ústavního soudu - viz PETROV, Jan. The COVID-19 emergency in the age of executive aggrandizement: what role for legislative and judicial checks? The Theory and Practice of Legislation, 2020, roč. 8, č. $1-2$, s. 92 .

11 Rozsudek Městského soudu v Praze ze dne 11. 11. 2020, sp.zn. 14 A 45/2020-131. Za upozornění na toto rozhodnutí děkuji recenzentovi článku.

12 Podrobnosti ohledně aplikace jednotlivých složek testu proporcionality zhodnotím níže v části 2.

13 Zároveň však souhlasím s těmi, kdo tvrdí, že redukovat diskusi o přijatých opatřeních na otázky kompetence a proporcionality znamená vynechat řadu obecnějších otázek legitimity státní moci, rozhodování státu ve výjimečných stavech, apod. Viz AGHA, Petr. Farmakon. In: ŠEJVL, Michal, Petr AGHA, Tomáš SOBEK, Jana KOKEŠOVÁ a David ČERNÝ. Vitězové a poražení: Právni a etické problémy současné koronakrize. Praha: Ústav státu a práva Akademie věd ČR, 2020, s. 34. 
není v době výjimečného stavu menší než mimo něj. ${ }^{14}$ Konkrétním důvodům, proč je důležité zkoumat kritérium proporcionality i ve výjimečných stavech, se budu věnovat v následující části. Ve třetí části se zaměřím na jednotlivé složky testu proporcionality a jejich zkoumání u opatření přijatých ve výjimečných stavech, zejména s ohledem na roli diskrece zákonodárce a exekutivy. Závěrečná část pak shrnuje především specifika aplikace principu proporcionality při opatřeních přijatých ve výjimečných stavech oproti klasickému zkoumání proporcionality opatření zasahujících do základních práv v čase „normality“. Zvláštní pozornost bude věnována otázce důkazního břemene při přezkumu proporcionality přijatých opatření, která souvisí s často diskutovanou otázkou odůvodnění protikrizových opatření. ${ }^{15}$

\section{Proporcionalita opatření jako podmínka jejich ústavnosti rovněž ve výjimečném stavu}

To, že v průběhu výjimečného stavu je zapotřebí zkoumat proporcionalitu přijatých opatření, odpovídá teorii, podle níž se i ve výjimečném stavu pohybujeme v určitém ústavním rámci. Kim Lane Scheppele a další současní autoři rozlišují legální a extralegální prrístup k zvládání výjimečného stavu. ${ }^{16}$ Typickým představitelem extralegálního přístupu byl německý ústavní teoretik Carl Schmitt, argumentující suverenitou, která se projevuje mimo jiné právě v době výjimečných stavů. Krize ostatně podle tohoto autora nemohou být normovány skrze obecná pravidla, protože jsou nepředvídatelné. ${ }^{17}$

$\mathrm{Na}$ jiném místě jsem argumentoval, že extralegální přístup může být $\mathrm{v}$ soudobém demokratickém právním státě zdrojem řady problémů, které mohou eventuálně vyústit až k zániku státního uspořádání v době „,normality“. ${ }^{18}$ Právo v době výjimečného stavu naplňuje zejména následující tři funkce:

1. stejně jako mimo výjimečný stav se jedná o nástroj regulace práv a povinností adresátů,

14 Lze též tvrdit, že řádná aplikace principu proporcionality posiluje význam základních práv, která jsou v současných demokratických právních státech stěžejní (k významu základních práv a jejich filozofickému zdůvodnění viz HAPLA, Martin. Theory of Needs as Justification of Human Rights: Current Approaches and Problems of Uncertainty and Normativeness. The Age of Human Rights Journal, 2018, roč. 6, č. 10, s. 1-2; HAPLA, Martin. Teorie lidských práv. In: SOBEK, Tomáš, Martin HAPLA a kol. Filosofie práva. Brno: Nugis Finem Publishing, 2020, s. 337-338).

15 Kriticky k nedostatku zdůvodnění mimořádných opatření Ministerstva zdravotnictví viz např. WINTR, Správní právo, 2020, op. cit., s. 292; Obecněji k významu odůvodnění aktů státní moci srov. DOLEŽAL, Kryštof. K legitimitě krizových stavů a diskreční pravomoci státní moci v nich. In: ANTOŠ, Marek a Jan WINTR. Ústavní právo a koronavirus. Praha: Leges, 2021 (v tisku).

16 SCHEPPELE, Kim Lane. Legal and Extralegal Emergencies. In: WHITTINGTON, Keith E., Daniel KELEMEN a Gregory CALDEIRA (eds.). The Oxford Handbook of Law and Politics. Oxford: Oxford University Press, 2008, s. 165.

17 SCHMITT, Carl. Political Theology. Four Chapters on the Concept of Sovereignty. Chicago: University of Chicago Press, 2005, s. 6-7.

18 ONDŘEJEK, Pavel. Výjimečné stavy a úskalí legality. In: BÍLKOVÁ, Veronika, Jan KYSELA a Pavel ŠTURMA (eds.). Výjimečné stavy a lidská práva. Praha: Auditorium, 2016, s. 54. 
2. představuje limit státní moci při činnosti směřující k odvracení výjimečného stavu,

3. je nástrojem obnovy normality. ${ }^{19}$

Všechny tyto funkce směřují k tomu, aby byl výjimečný stav pouze dočasným stavem a nestal se normou. ${ }^{20}$

Vrátím-li se zpátky $\mathrm{k}$ otázce ústavnosti přijatých opatření $\mathrm{v}$ době výjimečného stavu, Benátská komise ve své zprávě věnované současným protiepidemickým opatřením přijatým v různých státech světa cituje vedle dočasnosti nezbytnost a proporcionalitu jako podmínky zachování demokracie, vlády práva a respektu k základním právům. ${ }^{21}$ Benátská komise speciálně u proporcionality připomíná tu skutečnost, že vždy je vyžadována volba adekvátních prostředků státní regulace, speciálně je zdůrazňováno, že opatření nesmí být excesivní z hlediska závažnosti (severity) a z hlediska místa, na něž dopadají opatření (geographical area covered by the emergency measures). ${ }^{22}$

$\mathrm{V}$ této souvislosti je potřeba připomenout klíčový čl. 6 odst. 1 ústavního zákona č. 110/1998 Sb., o bezpečnosti České republiky, v platném znění, podle něhož „,[n]ouzorý stav se mirže vyblásit jen s uvedenim divvodì na urătou dobu a pro urắté území. Současně s yybláseném nouzového stavu musi vláda vymezit, která práva stanovená ve zvlástním zákonè a v jakém rozsahu se v souladu s Listinou základnich práv a svobod omezuji a keteré povinnosti a v jakém rozsabu se ukládaji. Podrobnosti stanovi zákon. “Ústavní soud k výkladu tohoto ustanovení dodává: „Rนirná povaha krizových opatreni ov̌rem nic nemèni na tom, ̌̌e tyto akty mohou být yydávány jen na základě zumocnèni a v mezích stanovených ústavnim porádkem a že jïmi nesmi být zasahováno do základnich práv a svobod v rozporu s Listinou. Tato skutečnost je výslouně zdìraznèna v c̀. 6 odst. 1 ústavního zákona o bezpečnosti Céské

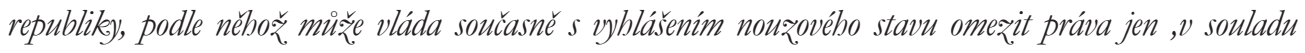
$s$ Listinou: Stanoveni urăté povinnosti nebo omezeni krizorým opatrením vlády neznamená, že by se vĩu základnímu právu nebo svobodè, do něbožje tímto zpuisobem zasahováno, neuplatnil požadavek podle čl. 4 odst. 4 Listiny, že pru použiváni ustanoveni o mezich základnich práv a svobod musi být šetreno jejich pod-

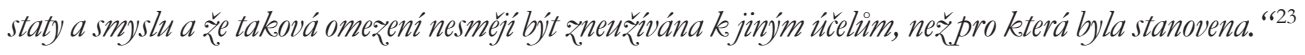

19 ONDŘEJEK, Pavel. Výjimečné stavy a úskalí legality. In: BÍLKOVÁ, Veronika, Jan KYSELA a Pavel ŠTURMA (eds.). Výjimečné stayy a lidská práva. Praha: Auditorium, 2016, s. 52-53.

20 ACKERMAN, Bruce. The Emergency Constitution. Yale Law Journal, 2004, s. 1044-1045; S odkazy na Agambenovy práce se tomuto nebezpeč́ věnuje rovněž Petr Agha: AGHA, Petr. Farmakon. In: ŠEJVL, AGHA, SOBEK, KOKEŠOVÁ, ČERNÝ, 2020, op. cit., s. 33-34; K nebezpečí permanentního výjimečného stavu srov. též KYSELA, Jan. Právo jako relativně uzavřený systém a dvojí pojetí výjimečného stavu. Předběžné ohledání schmittovského tématu. In: BÍLKOVÁ, KYSELA, ŠTURMA, op. cit., s. 36-37.

21 ALIVIZATOS, Nikos, Veronika BÍLKOVÁ, Iain CAMERON, Oliver KASK a Kaarlo TUORI. Respect for Democracy, Human Rights and the Rule of Law during States of Emergency - Reflections. Benátská komise [online] CDP-PI(2020)005rev ze dne 26. května 2020, s. 3-4 [cit. 5. 7. 2020]. Dostupné z: https:// www.venice.coe.int/webforms/documents/?pdf=CDL-PI(2020)005rev-e

22 Ibid., s. 4-5, odst. 11.

23 Usnesení Ústavního soudu ze dne 5. 5. 2020, sp. zn. Pl. ÚS 13/20, bod 24. Proporcionalitu opatření jako kritérium pro ústavně konformní omezení základních práv v době nouzového stavu explicitně zkoumá již zmíněný rozsudek Městského soudu v Praze ze dne 11. 11. 2020, sp. zn. 14 A 45/2020-131, odst. 75. 
Nutnost zkoumání proporcionality se dovozuje rovněž ze zákonných formulací vyžadujících přijetí opatření $v$,nezbytně nutném rozsahu a na nezbytně nutnou dobu“, případně o ,je-li to nezbytné k ochraně veřejného zdraví“ nebo ,je-li to nezbytné pro zamezení vzniku a šíření infekčních onemocnění. “24 Odkazujeme tím nejen na předchůdce současného principu proporcionality, kterým byl princip nezbytnosti zásahu do základních práv rozvinutý v pruském správním právu konce 19 . století, ${ }^{25}$ ale zejména na obdobnou formulaci „nezbytnosti v demokratické společnosti“ jakožto podmínky zásahu do základního práva, která se objevuje např́klad v Evropské úmluvě o lidských právech a z níž dovozujeme požadavek proporcionality přijatých omezení práv. ${ }^{26}$

Požadavek proporcionality opatření v souvislosti s výjimečnými stavy je kromě soudní praxe uznáván i českou ústavní teorií. ${ }^{27}$ Položme si však otázku, jaké by byly důsledky toho, kdybychom podmínku proporcionality opatření přijatých ve výjimečných stavech neuznávali.

$\mathrm{V}$ prvé řadě bychom žrejmě narazili na problém rozporu se zněním výše uvedeného čl. 6 odst. 1 ústavního zákona o bezpečnosti České republiky, který vyžaduje limitování základních práv v souladu s Listinou základních práv a svobod, kam požadavek proporcionality standardně řadíme. ${ }^{28} \mathrm{I}$ kdybychom od této pozitivněprávní úpravy odhlédli, nerespektováním proporcionality bychom otevřeli prostor pro přjímání plošných, širokých a dlouhotrvajících omezení základních práv, která by mohla limitovat zásadním způsobem celou škálu práv, aniž by se zkoumalo, zda jsou tato opatření vůbec způsobilá dosáhnout cíle odvrácení výjimečného stavu, pokud ano, zda jsou skutečně potřebná, a i kdyby byla, zda omezení práv nevede $\mathrm{k}$ daleko větší újmě než potenciální naplnění sledovaného cíle.

24 \5 odst. 1, \6 odst. 1 zák. č. 240/2000 Sb., o krizovém řízení a změně některých zákonů (krizový zákon), v platném znění. Uvedené př́klady související s ochranou veřejného zdraví nalezneme v \ 69 odst. 2, \84 odst. 1, \ 89 odst. 1 zák. č. 258/2000 Sb., o ochraně veřejného zdraví, v platném znění. Viz též ŠEJVL, Michal. Lidská práva v současné situaci. In: ŠEJVL, AGHA, SOBEK, KOKEŠOVÁ, ČERNÝ, 2020, op. cit., s. 16; Podobné formulace nalezneme v jiných krizových zákonech, např. \ 4 odst. 2 a \ 21 zák. č. 181/2014 Sb., o kybernetické bezpečnosti, v platném znění, upravující stav kybernetického nebezpečí a prováděná bezpečnostní opatření.

25 ONDŘEJEK, Pavel. Zrod a utváření principu proporcionality v poválečném německém ústavním právu. Acta Universitatis Carolinae - Iuridica, 2015, č. 3, s. 157-158.

26 K testu nezbytnosti v demokratické společnosti viz KOSAŘ, David. Omezení práv a svobod zaručených v Úmluvě. In: KMEC, Jiří, David KOSAŘ, Jan KRATOCHVÍL a Michal BOBEK. Evropská úmluva o lidských právech. Komentár. Praha: C. H. Beck, 2012, s. 131-116.

27 Viz z poslední doby články: DIENSTBIER, Jakub, Viktor DERKA a Filip HORÁK. Ústavnost mimořádných opatření podle zákona o ochraně veřejného zdraví. Právník, 2020, č. 5, s. 422; WINTR, Správní právo, 2020, op. cit., s. 283; BÍLKOVÁ, Veronika. Koronavirová krize a lidská práva. Policy Paper [online]. Ústav mezinárodních vztahů, s. 6 [cit. 5. 7. 2020]. Dostupné z: https://www.dokumenty-iir.cz/ PolicyPapers/2020/VBilkova_COVID19.pdf

28 KOSAŘ, David, ANTOŠ, Marek, KÜHN, Zdeněk a Ladislav VYHNÁNEK. Ústavní právo. Casebook. Praha: Wolters Kluwer, 2014, s. 362. 
Odpůrci zkoumání proporcionality opatření by mohli rovněž argumentovat z pozic modernější podoby extralegálního př́istupu k výjimečným stavům, která se objevuje po 11. září 2001 v právních stanoviscích administrativy prezidenta G. W. Bushe. Argument stavící efektivitu odvracení výjimečného stavu nad jakékoliv právní překážky je však stěží udržitelný, zejména vezmeme-li v potaz význam dodržování pravidel ze strany samotného státu pro legitimitu celé veřejné moci. Podíváme-li se blíže na extralegální argumentaci v americké praxi 21. století, lze konstatovat, že ji tamější Nejvyšší soud velkou většinou odmítl. ${ }^{29}$

Mírnější podobu extralegálního prrístupu představuje vytýčení oblasti, v níž je uznávána široká zdrženlivost (substantial deference), při níž soudy nejenže nepřezkoumávají uvážení, ale odmítají podobné př́ípady vůbec rozhodovat. ${ }^{30}$ Často diskutovaným tématem v této souvislosti je americká doktrína politické otázky anebo francouzská actes de gouvernement. ${ }^{31}$ Nabízí se určité srovnání s medicínskou otázkou, která by rovněž byla mimo přezkum soudů. Takovýto postup by však mohl znamenat př́liš široký prostor pro neprezkoumatelné akty exekutivy. ${ }^{32} \mathrm{~V}$ době výjimečného stavu by platila zásada: inter arma silent leges. ${ }^{33}$

Při porovnání legálního a extralegálního přístupu ke zvládání výjimečných stavů je podle mého názoru z hlediska uchování současné podoby právního státu a standardu ochrany lidských práv vhodnější legální přístup. Odmítneme-li extralegální přístup k řešení výjimečného stavu, logicky se musíme věnovat i ústavnímu přezkumu přijatých opatření. Legální přístup však má úskalí v podobě vytváření možných překážek pro efektivní reakci (jak je vidět na príkladu epidemie nemoci COVID-19, opatření mohou omezovat základní práva i velmi významně a současně v řadě př́ípadů musejí být přijímána velmi rychle).

Namísto definování prostoru, v rámci něhož by nedocházelo k přezkumu opatření exekutivy a legislativy ze strany soudů, je možné za druhé jako alternativu k proporcionalitě uvažovat vytvoření odlišného testu namísto testu proporcionality (opět se nabízí srovnání britské doktríny vyloučení nerozumné úpravy - unreasonableness, př́ípadně

29 SCHEPPELE, 2008, op. cit., s. 177.

$30 \mathrm{~K}$ rozdílu mezi minimální a širokou zdrženlivostí (minimal and substantial deference) viz KAVANAGH, Aileen. Deference or Defiance? The Limits of the Judicial Role in Constitutional Adjudication. In: HUSCROFT, Grant (ed.). Expounding the Constitution. Essays in Constitutional Theory. Cambridge: Cambridge University Press, 2008, s. 191.

$31 \mathrm{~V}$ české literatuře viz podrobné zpracování MALÍŘ, Jan. Actes de gouvernement v soudobém francouzském právu: kompromis mezi soudním přezkumem a politikou. Právník, 2018, č. 2, s. 89-114; MALÍŘ, Jan. Klasická doktrína politické otázky v kontextu limitů soudního přezkumu v USA. Jurisprudence, 2018, Č. 5, s. 15-29.

32 BRADY, Alan P. Proportionality and Deference under the UK Human Rights Act. An Institutionally Sensitive Approach. Cambridge: Cambridge University Press, 2012, s. 30.

33 SCHEPPELE, 2008, op. cit., s. 176. 
českého testu racionality). ${ }^{34}$ Argumentem pro tento postup by mohla být tvrzená př́ísnost testu proporcionality a potřeba aplikovat mírnější test. ${ }^{35}$ Nevýhoda tohoto postupu je oslabování jistoty účastníků ohledně toho, jaký test v hraniční věci použít, př́ípadně zda soud nevytvoří pro nový př́pad zcela nový test. Kromě toho Michal Šejvl představuje další argumenty proti aplikaci testu racionality: test racionality nezahrnuje kritérium nezbytnosti vyžadované legislativou, neaplikuje se standardně mimo sféru hospodáŕských, sociálních a kulturních práv a v prípadě zásahu do esenciálního jádra základního práva ( $\mathrm{k}$ čemuž v době výjimečných stavů často docházî), bývá dle judikatury Ústavního soudu aplikován jako kritérium přezkumu test proporcionality, nikoliv test racionality. ${ }^{36}$ Z výše uvedeného plynou výhody aplikace proporcionality jako kritéria přezkumu oproti alternativním modelům, které bud' zcela nebo zčásti přezkum vylučují, anebo aplikují alternativní test. Odkaz na potřebu zkoumání proporcionality však veškeré problémy sám o sobě nevyřeší. Je totiž nutné podrobněji se zaměřit na dílčí aspekty aplikace principu proporcionality v době výjimečného stavu. Konkrétně jde např́klad o to: Kdy, kým a jak má být proporcionalita zkoumána? Dále jde o posouzení toho, do jaké míry je současný test proporcionality vhodný pro aplikaci ve výjimečném stavu a do jaké míry je jej potřeba adaptovat?

V prvé řadě se ukazuje, že i ve výjimečných stavech je klíčové pro posouzení proporcionality či disproporce přijatých opatření zkoumání nejen právních, ale i skutkových otázek. V některých případech je však řešení skutkových otázek ve výjimečných stavech mimořádně obtížné. To dokládá například požadavek vlády, aby v řízení před Městským soudem v Praze bylo provedeno znalecké zkoumání, bez něhož podle vlády není možné

34 Literatura z posledních let k aplikaci testu racionality českým Ústavním soudem je rozsáhlá: ANTOŠ, Marek. Judikatura Ústavního soudu k sociálním právům: „nikoliv nutně nejlepší, nejvhodnější, nejúčinnější či nejmoudřejší'? Jurisprudence, 2014, č. 6, s. 3-14; ANTOŠ, Marek. EET, kouření, hospodářská práva a jaderná tlačítka. Jurisprudence, 2019, č. 3, s. 1-5; ČERVÍNEK, Zdeněk. Poměřovat, anebo nepoměřovat sociální práva? K otázce, zda lze test racionality považovat za variantu na metodu proporcionality. Jurisprudence, 2019, č. 3, s. 15-27; ČERVÍNEK, Zdeněk. Proportionality or Rationality in SocioEconomic Rights Adjudication? Case Study of Czech Constitutional Court's Judgment in Compulsory Vaccination Case. UCL Journal of Law and Jurisprudence, 2018, č. 1, s. 86-102; GRINC, Jan a Kristina BLAŽKOVÁ. Ústavní soud a zákonodárce v hospodářských a sociálních otázkách: ochrana ústavnosti, nebo přetahovaná o politice? Jurisprudence, 2019, č. 3, s. 6-15; KRATOCHVÍL, Jan. Test racionality: skutečně vhodný test pro sociální práva. Právník, 2015, č. 12, s. 1052-1074; MUSIL, Jan. Soudní ochrana sociálních práv. In: GERLOCH, Aleš, Pavel ŠTURMA a kol. Ochrana qákladních práv a svobod v proménách práva na poćátku 21. stoleti v českém, evropském a mezinárodnim kontextu. Praha: Auditorium, 2011, s. 69-79; ONDŘEJEK, Pavel. Princip proporcionality a jeho role prí interpretaci základnich práv a svobod. Praha: Leges, 2012, s. 164 a násl.; VYHNÁNEK, Ladislav. Proporcionálně či jinak? Problém ústavního přezkumu zásahů do sociálních práv. Casopis pro právní védu a praxi, 2014, č. 3, s. 203-221; WINTR, Jan. První tři dny nemoci bez nemocenského a ústavní přezkum zákonné úpravy sociálních práv. Jurisprudence, 2008, č. 5, s. 31-39.

35 ŠEJVL, Michal. Lidská práva v současné situaci. In: ŠEJVL, AGHA, SOBEK, KOKEŠOVÁ, ČERNÝ, 2020, op. cit., s. 19.

36 Ibid. 
exaktní test proporcionality provést. ${ }^{37} \mathrm{~V}$ daném sporu obě jeho strany následně ponechaly na soudu to, zda nechá vypracovat znalecký posudek za účelem posouzení proporcionality daného opatření. ${ }^{38}$ Soud ji však nakonec meritorně nepřezkoumával.

Soudce Jan Filip naznačil další problém v disentu k usnesení Pl. ÚS 8/20 (tedy v „pilotním“ rozhodnutí Ústavního soudu odmítajícím stížnost o porušení svobody pohybu v době nouzového stavu v České republice). Podle něj pro opatření přijatá ve výjimečném stavu „obecně platí, že jsou vydávána na základě uváženi prǐslušnébo orgánu výkonné moci,

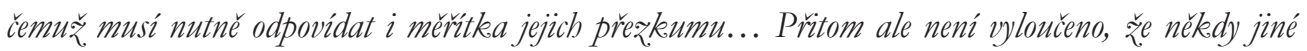
nežjediné rèseni nebude pricházet do úvaby... bez obledu na to, kolik se ,po válce' objeví generáli. Jde

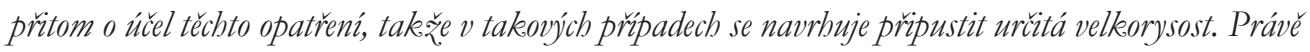
uvedeni autori hovoř o prĭjatelnosti trpèné nezákonnosti (geduldene Illegalität') pr̆ hodnoceni ak.ti správního uváženi. "39 V této souvislosti se lze ptát, zda existuje obdobná přijatelná míra disproporcionality opatření přijímaných ve výjimečných stavech?

Oba výše naznačené problémy poukazují na klíčovou otázku intenzity přezkumu proporcionality a s tím související požadavek na zdrženlivost soudů při přezkumu aktů přijatých na základě odborného posouzení veřejné správy v době výjimečného stavu.

\section{Aplikace jednotlivých složek testu proporcionality ve výjimečných stavech}

Výše zmíněnou zdrženlivost naznačují i české soudy nejen tím, že fakticky proporcionalitu opatření nepřezkoumávají a nenahrazují tak svým úsudkem uvážení exekuti$\mathrm{vy}^{40} \mathrm{Z}$ hlediska různých modelů zdrženlivosti soudu se domnívám, že je postupováno správně, když soudy uznávají princip proporcionality jako kritérium préezumu ústavnosti i v době výjimečného stavu. Namísto vyloučení oblastí z přezkumu anebo vytvoření odlišného testu se mi jeví jako vhodnější postup přizpơsobení univerzálního testu proporcionality v jeho jednotlivých složkách. Obdobně argumentuje Alan Brady, když o proporcionalitě a zdrženlivosti (deferenci) hovoří o fenoménech, které jsou spolu propojeny, přičemž tomuto propojení je potřeba porozumět, tak abychom lépe pochopili aplikaci principu proporcionality. ${ }^{41}$

\footnotetext{
37 Rozsudek Městského soudu v Praze ze dne 23. 4. 2020, sp. zn. 14 A 41-2000, odst. 43: „dle odpuirce v daném prïpadě neni možné provést exaktni test proporcionality, jak indikuje návrh, a tím určit, jaké opatreni je objektivně lepši (proporcionálnèjš̀) než drubé."

38 Ibid., odst. 67.

39 Odlišné stanovisko soudce J. Filipa k usnesení Ústavního soudu ze dne 22. 4. 2020, sp. zn. Pl. ÚS 8/20, bod 34.

$40 \mathrm{~K}$ problematice soudního přezkumu a proporcionality v českém správním soudnictví srov. KÜHN, Zdeněk a Josef STAŠA. Deference to the administration in judicial review in the Czech Republic. The Lawyer Quarterly, 2018, č. 4, s. 360-361.

41 BRADY, 2012, op. cit., s. 31.
} 
Postupně lze identifikovat tři důvody pro uplatnění širší míry soudcovské zdrženlivosti:

- V rámci výjimečného stavu, kde se projevují ohrožení některého z veřejných zájmů chráněných právem, vystupuje do popředí důvod spočívající v nedostatku odbornosti v určité oblasti (např́iklad v oblasti zvládání epidemie), což silně omezuje možnosti soudu nahradit vlastním uvážením expertní rozhodnutí. ${ }^{42}$

- V menší míre se uplatňuje argument o nevhodnosti rozhodování o komplexních otázkách, které je vhodné pro legislativní normotvorbu, nikoliv soudní dotváření práva (vzhledem $\mathrm{k}$ tomu, že soudům chybí celá řada relevantních informací pro vydání takovéhoto rozhodnutî). ${ }^{43}$

- Relativně nejméně se uplatní argument demokratickou legitimitou, ${ }^{44}$ protože způsob prijímání rozhodnutí ve výjimečném stavu obvykle není založen na demokratické deliberaci, nýbrž na byrokratickém expertním rozhodnutí, s nímž demokraticky zvolené orgány souhlasí.

Pokud se zaměřím na jednotlivé dílčí složky testu proporcionality, test vhodnosti nám odpovídá na otázku, zda je opatření vưbec zpơsobilé dosáhnout legitimního cíle, za jehož účelem bylo přijato. V rozhodnutí týkajícím se přezkumu mimořádného opatření o zákazu osobní přítomnosti žáků na výuce se Městský soud v Praze věnoval rovněž požadavku proporcionality, který „nelze posuzovat izolovanè, bezp prihlédnuti k relevantním skutkovým okolnostem a uznávanému stavu védeckého poznání. Pokud by žalovaný postupoval zpüsobem żevnè rozporným s relativně ustáleným stavem védeckébo poznáni a zasahoval do základních práv prokazatelně neúčlnými postupy, jednalo by se o relevantni právni bledisko prí soudním prézkumu. Takto jednoduchá však situace zpravidla v krizových situacich nebývá a neni taková ani v nyní projednávané věci. " 45 To samožrejmě neznamená, že by nemohlo být přijato opatření zcela nevhodné k dosažení určitého legitimního cíle. Př́kladem je mad’arský zákon ze dne 30. března 2020, který mimo jiné kriminalizoval sdělování skutečností, které narušují „úspěšnou ochranu“ veřejnosti. ${ }^{46}$ Mad'arská autorka působící v Německu Kriszta Kovács upozorňuje na fakt, že zákon bude platit i po skončení pandemie a bude patrně využíván $\mathrm{k}$ odstrašení kritiků vlády. ${ }^{47}$ Problematická nová úprava regulující tisk nebo jinak zasahující do svobody projevu se objevila rovněž v Číně, Turecku nebo Íránu. ${ }^{48}$

42 KAVANAGH, 2008, op. cit., s. 194 a násl.

43 Ibid., s. 193-194.

44 Ibid., s. 200 a násl.

45 Rozsudek Městského soudu v Praze ze dne 7. 5. 2020, sp. zn. 10 A 35/2020-261, odst. 84.

46 KOVÁCS, Kriszta. Hungary's Orbánistan: A Complete Arsenal of Emergency Powers. Verfassungsblog [online]. 6. 4. 2020 [cit. 5. 7. 2020]. Dostupné z: https://verfassungsblog.de/ hungarys-orbanistan-a-complete-arsenal-of-emergency-powers /

47 Ibid.

48 YILDIZ, Ali. Human Rights in a State of Emergency. LACL-AIDC Blog [online]. 26. 3. 2020 [cit. 5. 7. 2020]. Dostupné z: https://blog-iacl-aidc.org/2020-posts/2020/3/26/human-rights-in-a-state-of-emergency 
Existuje-li více možností právní úpravy, z nichž všechna jsou vhodná k dosažení cíle, poté se v této fázi testu proporcionality nehledá vhodnější řešení. Proto, aby byl splněn první krok testu proporcionality, postačí naopak způsobilost přijatého opatření ve vztahu k legitimnímu cíli. Ve výjimečném stavu sice nedochází k modifikaci testu vhodnosti oproti jeho aplikaci v běžných př́padech, co se však liší, mưže být kontext plynoucí z výjimečného stavu. To, zda bylo opatření racionální s ohledem na stav poznání v době jeho přijetí, se může lišit oproti tomu, jak danou situaci hodnotíme s odstupem času. Proto testem vhodnosti neprojde pouze opatření, které bychom mohli hodnotit už v době jeho přijetí s ohledem na stav poznání př́íslušných rizik jako nevhodné k dosažení cíle.

V rámci argumentace principem potřebnosti je za běžných okolností nutno přesvědčivě argumentovat, že jiná, podobně efektivní opatření nezasahují do dotčených práv méně. ${ }^{49}$ Ve výjimečném stavu nastupují specifika daná určitou mírou nejistoty v době príjetí opatření. Potřebnost je tedy vždy třeba posuzovat podle toho, co příslušným orgánům mohlo a mělo být v době přijetí př́islušného opatření známo. ${ }^{50}$ Tento požadavek navrhovaný M. Šejvlem se mi jeví rozumný, protože na jednu stranu nehodnotí zpětně výsledky přijatého opatření s ohledem na to, co je známo po skončení výjimečného stavu (viz výše uvedený citát z disentu soudce J. Filipa o tom, kolik se po bitvě objeví generálů). Na druhou stranu však vyžaduje i aktivní kroky vlády v tom směru, aby přjímala rozhodnutí na základě vědeckých (nikoliv ideologických, či politických) úvah. V tomto ohledu lze odkázat na dlouhou dobu přetrvávající odpor k nošení obličejových roušek ze strany představitelů republikánské strany USA, a to i v době, kdy se názory vědecké komunity jednoznačně přiklonily $\mathrm{k}$ názoru, že roušky jsou efektivním prostředkem omezujícím šírení nákazy nemoci COVID-19.

49 Při zkoumání zákazu vycestovat mimo ČR Městský soud v Praze správně zhodnotil efektivitu alternativních prostředků regulace: „Soud si je védom, že legitimního cíle moblo být dosaženo také napríklad vyžadováním negativního testu na koronavirus. Toto opatreni by však nebylo schopno verejné zdravi ochránit ve srovnatelné míre. Př kaそ̌dodennich cestách se žalobkyně mobla nakazit kterýkoliv den. Prïtom s obledem na nutnost vyhodnoceni PCR testu, který neni okamžitý, nebylo možné požadovat každý den aktuální negativni test. Naví je otážou, żda každý den nový PCR test by byl sobledem na svou značnou nákladnost pro práva žalobkynè šetrnèjǔi. Negativni test z. několik dni starébo vyšetrení by nezaručil, že žalobkyně není nakažlivá v daný den" (rozsudek Městského soudu v Praze ze dne 11. 11. 2020, sp. zn. 14 A 45/2020-131, odst. 100).

50 ŠEJVL, Michal. Lidská práva v současné situaci. In: ŠEJVL, AGHA, SOBEK, KOKEŠOVÁ, ČERNÝ, 2020, op. cit., s. 19; Městský soud v Praze v rozsudku o zákazu vycestovat mimo ČR týkajícím se některých přeshraničních pracovníků uvádí, že „[v] počátcich pandemie nejde po vládě požadovat, aby pro všechny své kroky mèla pečlivé analýż, že se jedná o opatrení, které je v dané situaci nezbytné z dưvodu ochrany verejnébo zdraví. Zákaz vycestováni obsahoval nèkolik. vyjimek, mimo jiné pro preshranični pracouníky jako je žalobkyně. Vláda tedy neprijala plošný zákaz vycestování. Byla si patrnè vědoma, že takové opatrení by bylo neprĭpustné. Zároveñ však véděla, že koronavirus se do Ceské republiky dostal ze zahranič. Považovala tedy za potrebné, aby omezila preshranični cestování.. Nicméné ani v tomto obledu se nejednalo o plošné opatrení. Propendlery do Polska a Slovenska omezeni neplatilo. Vláda tedy vzala v potaz prǐznivèjš́s epidemiologickou situaci v tèchto zemich ve srovnáni s Nèmeckem a Rakouskem." (rozsudek Městského soudu v Praze ze dne 11. 11. 2020, sp. zn. 14 A 45/2020-131, odst. 98-99). 
Takovýto přístup rovněž respektuje požadavek předběžné opatrnosti. ${ }^{51}$ Přes snížený požadavek na přesnost zdůvodnění je však nutné naznačit, jaké alternativní prostředky byly zvažovány, a ukázat důvody, které vedly právě k tomuto rozhodnutí. Problémy při argumentaci potřebností přijatého opatření rovněž vyjádřil Městský soud v Praze v rozhodnutí ze dne 7. 5. 2020: „Žalovaný byl [...] nucen rychle reagovat na broz̧bu pandemie, o níz. existuje jen kusé, neustálené a stále se dynamicky vyvijejici védecké poznání. Vedle toho se neustále mèní i skutkové okolnosti spočivajici zejména v počtech a geografickém rozloženi nemocných stejnè jako konkrétnich projevech nemoci, respektive informacich o nich. Mire nejistoty musi býtprímo úmèrný i prostor žalovaného pro wážení. "52

Právě určitá míra nejistoty ohledně vývoje epidemiologické situace se projevila zejména v požadavku předběžné opatrnosti, což vedlo k urychlenému omezování celé rady práv. Zároveň však přezkum rozhodnutí prüijatých s ohledem na princip předběžné opatrnosti vyžaduje přiznání určité míry diskrece; bylo by totiž nanejvýš problematické, pokud by se soudy snažily hodnotit, zda by v prrípadě mírnějších protiepidemických opatření mohlo být např́klad dosaženo požadovaného cíle. K vyslovení takovéhoto závěru by podle mého názoru chyběly jednoznačné důkazy.

S problematikou potřebnosti souvisí rovněž otázka porovnání jednotlivých omezení. Silným argumentem proti potřebnosti opatření omezujících zasedání zastupitelstev územních samosprávných celků je proto skutečnost, že ve stejné době existovaly výjimky pro výkon povolání, kde např́klad nebyl nikdy omezen počet současně přítomných osob v jedné místnosti. ${ }^{53}$

V poměřování, tedy třetím kroku testu proporcionality, obecně zkoumáme, zda je újma na jednom právu nebo veřejném zájmu vyvážena př́inosem na kolidujícím právu nebo veřejném zájmu. ${ }^{54}$ I zde se projevuje silným způsobem nejistota ohledně přesných účinků přijatého opatření, a př́ipadně i některé důsledky omezení práva mohou být nezamýšlené. ${ }^{55}$

51 Tomáš Sobek hodnotí význam principu předběžné opatrnosti při rozhodování v době výjimečných stavů jako rozhodování o přijatelném riziku. Spíše je potřeba vycházet z toho, že katastrofa hrozí, než že nehrozí, protože i při přijetí přísnějších opatření jsou důsledky lepší než v opačném případě, kdy dojde k podcenění nebezpečí. V podrobnostech viz SOBEK, Tomáš. Jaké je to být odepsaný. In: AGHA, Petr. Farmakon. In: ŠEJVL, AGHA, SOBEK, KOKEŠOVÁ, ČERNÝ, 2020, op. cit., s. 40-41.

52 Rozsudek Městského soudu v Praze ze dne 7. 5. 2020, sp. zn. 10 A 35/2020-261, odst. 84.

53 MAINCLOVÁ, Eliška. Právo na samosprávu během pandemie. In: ANTOŠ, Marek a Jan WINTR (eds.). Ústavni právo a koronavirus. Praha: Leges, 2021 (v tisku).

54 Není na tomto místě detailně popisovat různé přístupy $\mathrm{k}$ poměřování, př́ipadně kritiku takovéhoto postupu. Např́iklad Kai Möller uvádí, že řešení kolizí základních práv nemá být založeno na utilitaristické argumentaci - MÖLLER, Kai. Balancing and the Structure of Constitutional Rights. International Journal of Constitutional Law, 2007, roč. 5, č. 3, s. 462; na druhou stranu ale neplatí tvrzení, že utilitarismus je neslučitelný s koncepcí lidských práv - k tomuto argumentu podrobněji viz HAPLA, Martin. Utilitarismus a lidská práva. Casopis pro právni védu a praxi, 2020, roč. 28, č. 3, s. 321-336.

55 Robert Alexy ve vážící formuli hovoří o empirické i normativní spolehlivosti - v českém překladu Jana Broze viz ALEXY, Robert. Lidská důstojnost a princip proporcionality. Právník, 2015, č. 11, s. 871. 
V případě, že opatření nevyvolává požadované účinky, prrípadně není dostatečně efektivní, je potřeba opatření změnit. Totéž platí o situaci, kdy s postupujícím časem vyjdou najevo určité nové skutečnosti týkající se efektivity přijatých opatření.

K naznačeným krokům testu proporcionality je potřeba doplnit obecnější specifika pro aplikaci tohoto testu v rámci výjimečných stavů. První skupina souvisí s časovým aspektem proporcionality opatření: především je třeba zdůraznit, že omezující opatření směrující k odvracení krizového stavu mají být dočasná (např́klad trvalá opatření přijímaná kvưli probíhající epidemii nejsou přiměřená). Konkrétní opatření je třeba odlišit od trvalých systémových změn měnících obecná pravidla pro regulaci výjimečných stavů. Kromě toho je významné, že stejně jako v jiných př́padech i při přezkumu opatření přijatých $v$ rámci výjimečných stavů je možná následná protiústavnost původně proporcionálního opatření. Jedná se o jeden z důsledků vazby proporcionality na faktický stav a vyplývá z něj požadavek trvajícího zkoumání proporcionality opatření v průběhu času. Tak např́iklad zákaz vycházení z domovů může být sice proporcionální v čase extrémního nebezpečí nákazy, nicméně v době, kdy již riziko pominulo, by nezrušení tohoto opatření vedlo k jeho protiústavnosti. Př́ípadný přezkum však musí zohlednit druhou důležitou stránku, kterou je míra nejistoty ohledně řady proměnných, které majî být př̀zkoumávány.

Z této druhé charakteristiky vyplývá jednak požadavek zdrženlivosti vůči expertnímu posouzení dané věci, dále je pak vhodné aplikovat určitou míru zvýšené opatrnosti, pokud se nacházíme ve stavu nejistoty (viz např́klad současnou nejistotu ohledně míry šírení nemoci COVID-19, dopadů prodělání této nemoci na zdraví, rizikových faktorů a definování okruhu zranitelných osob apod.).

Poslední okolnost, na kterou se v tomto ohledu zaměřím, je otázka disproporcionality nedostatečně zdůvodněného opatření přijatého ve výjimečném stavu. Aniž bych zpochybňoval potřebu odůvodnit jakékoliv rozhodnutí veřejné moci zasahující do práv jednotlivců, domnívám se, že samotná nedostatečnost odůvodnění neznamená automaticky disproporcionalitu daného opatření. Absence odůvodnění však pravidelně bývá problémem z hlediska legitimity veřejné moci spojené s požadavkem justifikace. ${ }^{56}$ Principiálně je požadavek justifikace zásahů do základních práv požadavkem legitimity jejich omezení a je rovněž součástí naší kultury. Nežijeme totiž v kultuře autority, kde by zásahy do práv nebylo potřeba zdůvodňovat, případně by postačil odkaz na autoritu, která tato

$56 \mathrm{~K}$ potřebě ospravedlnění obecně v souvislosti s principem proporcionality viz též COHEN-ELIYA, Moshe a Iddo PORAT. Proportionality and Constitutional Culture. Cambridge: Cambridge University Press, 2013, s. 103 a násl.; Absence parlamentní diskuse a zdůvodnění však mohou představovat problém, na který upozornil Evropský soud pro lidská práva, když shledal britský zákon jako rozporný s Evropskou úmluvou v prrípadu Hirst vs. Spojené Království (̌́. 2) - rozsudek ze dne 6. října 2005, stížnost č. 74025/01. V podrobnostech viz WINTR, Jan a Daniel ASKARI. The Role of Parliamentary Autonomy in Constitutional Review. The Lawyer Quarterly (v tisku). 
opatření vydala. ${ }^{57} \mathrm{~V}$ rozsudku, kterým Městský soud v Praze zrušil mimořádné opatřní Ministerstva zdravotnictví ze dne 19. 10. 2020 právě pro nedostatky odůvodnění, se mimo jiné uvádí: „VÝkon verejné správy by... mèl být stavèn primárnè na síle argumentù a nikoli na autorité rozhodujicího orgánu. Základním účelem odivvodnèni je proto vysvètleni skutkových a právnich divvodù pro prijeti rozhodnuti (jiného správního aktu) tak, aby jeho adresáti védèli, proč správni orgán takto rozhodl, a aby se proti nèmu mobli bránit, př́padnè $i$ podáním návrhu k soudu. Aby

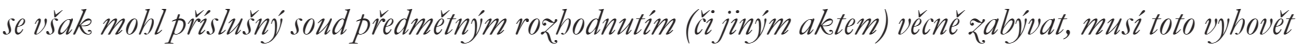
základnim požadavkìm kladeným na jeho prezkoumatelnost. "58

Absence důvodů představuje problém zejména u individuálních či obecně konkrétních aktů, kde je odůvodnění vyžadováno zákonem. V prrípadě opatření přijatých v době výjimečných stavů reflektuje odůvodnění rovněž větší či menší míru nejistoty ohledně řady faktorů, a také citlivost dané problematiky (kalkulování s počty obětí je pravidelně záležitost, která může být eticky problematická a také politicky neúnosná, nicméně adekvátní zvládnutí krizové situace může tyto úvahy vyžadovat).

Z výše uvedených důvodů je požadavek na vlastní zdůvodnění přijatého opatření méně přísný. $\mathrm{V}$ každém případě je však třeba argumentovat tak, aby zdůvodnění nebylo jen formální. Souhlasím tedy s názorem Městského soudu v Praze, který k této otázce dodává: „Je v̌̌ak treba na základě 178 odst. 1 správníbo rádu aplikovat základní zásadu činnosti správnich orgánu kodifikovanou v $\int 2$ odst. 2 správníbo rádu, dle niž správni orgán uplatñuje svou pravomoc pouze ke tèm účllìm, k nimž mu byla zákonem nebo na základě zákona svèrena. Aby bylo dodrženi této zásady prezkoumatelné, musi ministerstvo v mimorádném opatreni uvést dìvody jeho vydání. Na mimoŕádná opatreni vydaná v době epidemie jistě nelze mit prépjatě formalistické po žadavky, a v závislosti na okolnostech tedy mưže postačovat i odìvodnèni relativně stručné. Na druhé

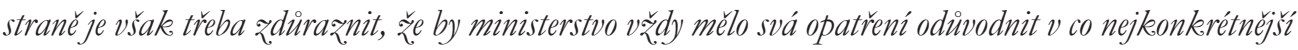

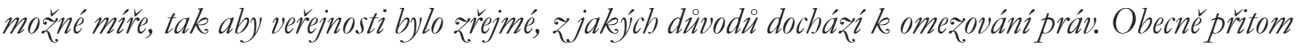
plati, že s postupujicím časem od začátku epidemie lze predpokládat vyšši informovanost ministerstva o brozicicich rizicich i o nèco nižši potréebu rychlých reakcí, a proto by méla být mimořádná opatreni odüvodňována podrobnéji. "59

Požadavky na zdůvodnění přjiatých opatření rozvedl Městský soud v Praze v rozsudku ze dne 20. října 2020, kterým zrušil nařízení Hygienické stanice hl. m. Prahy č. 12/2020 zakazující osobní př́tomnost studentů při studiu na pražských vysokých školách. V tomto rozhodnutí nejprve soud kritizoval, že předmětné opatření obecné povahy neobsahuje konkrétní důvody, proč bylo přikročeno k uzavření jen vysokých škol, nikoliv jiných škol

57 COHEN-ELIYA, PORAT, 2013, op. cit., s. 103; K rozlišování kultury autority a kultury ospravedlnění viz klasický text: MUREINIK, Etienne. „A Bridge to Where?“ Introducing the Interim Bill of Rights. South African Journal on Human Rights, 1994, roč. 10, s. 31-48; V české literatuře viz např. ČERVÍNEK, 2018, op. cit., s. 371-373.

58 Rozsudek Městského soudu v Praze ze dne 13. 11. 2020, sp. zn. 18 A 59/2020-224, odst. 136.

59 Rozsudek Městského soudu v Praze ze dne 7. 5. 2020, sp. zn. 10 A 35/2020-261, odst. 62. 
anebo např́klad barů, restaurací, obchodních center, sportovišt' apod. ${ }^{60}$ Následně uvádí, že „absolutni nedostatek odìvodnèni zdiovodnèni prĭjatého zákazu znemožnuje prezkum napadeného opatreni z. hlediska jeho proporcionality. " 61 V pozdějším rozsudku ze dne 13. listopadu 2020 tentýž soud uvádí, že „[a]ni výjimečnost celé situace pritom nemůže být automaticky omluvou odpuirce pro ulebčeni si práce's oduivodňováním mimorádných opatreni: i v době nouzového stavu je nepochybně zádouci trvat na dodržováni určitých základnich standardi kladených na postup verejné správy a na prịimáni správnich aktů, mimorádná opatreni podle zákona o ochranè verejného zdravi nevyjimaje... Soud zde podotýká, že nyni se nacházime již témèr trù čturtě roku od vypuknuti epidemie (nebo minimálnè hrozby epidemie) v České republice v breznu 2020, a prestože lze zrérmé opèt hovorìt o vážné až mimorádné situaci, odpirre by již mèl být schopen dostát požadavkeim na prezkoumatelnost odiovodnèní jím vydávaných mimorádných opatreneni daleko lépe než na jaře. "662

Přestože na odůvodnění některých opatření v době jejich přijetí můžeme mít ve výjimečných stavech poněkud nižší nároky, situace se diametrálně změní ve chvíli, kdy dojde k soudnímu sporu, v němž je posuzována platnost či ústavnost tohoto opatření. Zde musí stát, potažmo jeho orgány, dokázat, že přijatá opatření jsou vhodná, potřebná a přiměřená. ${ }^{63}$ Břemena tvrzení a argumentační břemena se přitom neliší od jiných sporů týkajících se proporcionality: protiústavnost tvrdí a prokazuje navrhovatel, ${ }^{64}$ tvůrce př́slušného opatření (vláda, ministerstvo, parlament) následně argumentuje jeho proporcionalitou. ${ }^{65}$ $\mathrm{Na}$ samém počátku sporu tedy břemeno tvrzení a argumentace není na státu. Pokud by tomu tak bylo, argument potřebnosti přijaté právní úpravy by např́iklad v konečném důsledku vyžadoval zkoumání nekonečného množství alternativních úprav. ${ }^{66}$

60 Rozsudek Městského soudu v Praze ze dne 20. 10. 2020, sp. zn. 5 A 3/2020-47, odst. 10.

61 Ibid., odst. 13.

62 Rozsudek Městského soudu v Praze ze dne 13. 11. 2020, sp. zn. 18 A 59/2020-224, odst. 149.

63 Viz rovněž vyjádření Jana Kysely. Kysela: Na zavřené hranice si nesmíme zvyknout. Je vidět, jak snadné je šírit strach. DVTV [online]. 21. 4. 2020 [cit. 5. 7. 2020]. Dostupné z: https://video.aktualne.cz/dvtv/ kysela-na-zavrene-hranice-si-nesmime-zvyknout-je-videt-jak-s/r 2a9a9fa8834211eab0f60cc47ab5f122/

64 V tomto ohledu je zajímavý rozsudek Městského soudu v Praze ze dne 11. 11. 2020, v němž soud zamítl návrh žalobkyně, přičemž v odůvodnění konstatuje, že byt' je vyjádření týkající se přmiměřenosti opatření ze strany vlády velmi obecné, ,žalobkyně sama žádnou bližsí argumentaci oblednè nepriměrenosti dopadu krizovébo opatrení nevznáší. "(rozsudek Městského soudu v Praze ze dne 11. 11. 2020, sp. zn. 14 A 45/2020-131, odst. 104).

65 Důvodem, proč by měla být v odůvodnění soudního rozhodnutí detailně popsána proporcionalita příslušného opatření, spočívá také v tom, aby dané rozhodnutí bylo racionální a přesvědčivé, chápeme-li soudní rozhodnutí jako dialog soudu s účastníky řízení, potažmo s dalšími soudy, které budou rozhodovat v téže nebo v podobné věci - GAZDA, Viktor. Variace na téma axiologických východisek aplikace práva. In: ̌̌ÁK KRZYŽANKOVÁ, Katarzyna, Zdeněk KÜHN, Karel BERAN, Pavel MARŠÁLEK, Jan WINTR, Pavel ONDŘEJEK a Jan TRYZNA (eds.). Právo jako multidimenz̨ionálni fenomén. Pocta Aleši Gerlochovi k 65. narozeninám. Plzeň: Aleš Čeněk, 2020, s. 531; K významu diskurzu při ústavním přezkumu pro zlepšení veřejné deliberace srov. KLATT, Matthias. Judicial review and institutional balance. Comments on Dimitrios Kyritsis. Revus, 2019, č. 38, s. 31.

66 BARAK, Aharon. Proportionality. Constitutional Rights and Their Limitations. Cambridge: Cambridge University Press, 2012, s. 449. 


\section{Závěr}

Princip proporcionality je jakožto univerzální kritérium přezkumu ústavnosti nezbytné uplatňovat i při přezkumu opatření přijatých ve výjimečných stavech. ${ }^{67}$ Výše zmíněné alternativy v podobě doktríny zdrženlivosti zcela vylučující přezkum určitých otázek, anebo vytváření nových testů jsou podle mého názoru deficitní. V prvém prúpadě je tomu tak z hlediska současného standardu ochrany základních práv, ve druhém pak z důvodu požadavku právní jistoty adresátů práva. Zároveň se však nedomnívám, že by veškeré otázky ústavnosti či zákonnosti, a tím spíše ne otázky správnosti přijatých opatření, bylo možné řšsit pouze s odkazem na argumenty proporcionality.

Proporcionalita současně vyžaduje zhodnocení adekvátní míry zdrženlivosti v rámci jednotlivých kroků testu proporcionality. Zdrženlivost reflektuje nejistotu ohledně celé řady skutečností doprovázejících opatření přijímaná ve výjimečném stavu, dále princip předběžné opatrnosti, který je preferovaný z důvodu přijatelnějších důsledků hrozících rizik. Konečně, vyšší míra zdrženlivosti soudů by měla reflektovat expertní uvážení, a dále v určité míře i komplexnost řešených otázek.

Přes požadovanou zdrženlivost je potřeba aplikovat test proporcionality na přezkum každého dílčího prrijatého opatření. Dále lze vyžadovat přezkum trvání přiměřenosti opatření v čase, kde bychom zkoumali to, zda v minulosti zdůvodněná přiměřenost opatřné trvá. ${ }^{68} \mathrm{~V}$ př́ípadě sporu můžeme vyžadovat podrobné zdůvodnění proporcionality daného opatření v době jeho přijetí ze strany orgánu, který opatření vydal. Přitom však prvotní argument o tvrzené nepřiměřenosti musí předložit stěžovatel.

$67 \mathrm{~K}$ důležitosti ochrany základních práv v mimořádných stavech, kdy existuje zvýšené riziko porušování základních práv, srov. rozsudek Nejvyššího správního soudu ze dne 13. 5. 2020, sp. zn. 6 Azs 89/2020-22, odst. 23, a rozsudek téhož soudu ze dne 4. 6. 2020, sp. zn. 6 As 88/2020-44, odst. 63.

68 Souhlasit lze i s názorem Městského soudu v Praze, že časový aspekt hraje roli i při hodnocení intenzity přezkumu (a tedy míry zdrženlivosti). „Velká deference tedy již. nemusí být opodstatněna v poz̧dèjšich fázich pandemie, kedy lze od vlády očekávat, aby svá rozhodnuti prịimala na základě presných informaci a sobledem na princip minimalizace zásahu do základních práv." (rozsudek Městského soudu v Praze ze dne 11. 11. 2020, sp. zn. 14 A 45/2020-131, odst. 108). 